\title{
Leishmania infantum infection in dogs from maroon communities in the Eastern Amazon
}

\author{
Andréia Ferreira da Silva ${ }^{1}$ Ágatha Rossanni Alves Damasceno ${ }^{1}$ Welton Seabra Prado ${ }^{1}$ Rossela

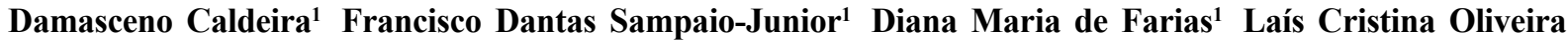 \\ da Silva ${ }^{1}$ Ricardo José de Paula Souza e Guimarães ${ }^{2}$ Gustavo Góes-Cavalcante ${ }^{1}$ Alessandra Scofield ${ }^{1 *}$
}

${ }^{1}$ Laboratório de Parasitologia Animal, Instituto de Medicina Veterinária, Universidade Federal do Pará (UFPA), Campus Castanhal, BR 316, Km 61, 68740-080, Castanhal, PA, Brasil. E-mail: ascofield@ufpa.br. "Corresponding author.

${ }^{2}$ Laboratório de Geoprocessamento, Instituto Evandro Chagas (IEC), BR 316, Ananindeua, PA, Brasil.

\begin{abstract}
This study was designed to detect $\boldsymbol{L}$. infantum infection in dogs and to evaluate the factors associated with canine visceral leishmaniasis in the maroon communities of Menino Jesus de Petimandeua and Itaboca in the municipality of Inhangapi, Pará, Brazil. Whole blood and intact skin samples were collected from 143 dogs, and a questionnaire was applied. L. infantum DNA was detected by polymerase chain reaction (PCR) using primers RV1 and RV2. Collection sites were georeferenced to obtain a spatial distribution of the residences visited and infected dogs. L. infantum DNA was detected in 8.4\% (12/143) of the skin samples and in 1.4\% (2/143) of the blood samples. On the risk map, three clusters were observed in Itaboca and one was observed in Menino Jesus de Petimandeua. We observed that most of the inhabitants in these maroon communities live close to forested areas and do not use protection against insect vectors. The presence of canine reservoirs of $\boldsymbol{L}$. infantum associated to environment characteristics (preserved forests and deforested areas) and habits of dog owners (living near forested areas and not using any protection against insects) may favor the transmission of $\boldsymbol{L}$. infantum in the studied areas.
\end{abstract}

Key words: Leishmania infantum, maroon communities, dog, PCR, Eastern Amazon.

Infecção por Leishmania infantum em cães de comunidades quilombolas na Amazônia Oriental

RESUMO: O presente estudo objetivou detectar a infecção por Leishmania infantum em cães e avaliar os fatores associados com a leishmaniose visceral canina nas comunidades quilombolas Menino Jesus de Petimandeua e Itaboca, municipio de Inhangapi, Pará, Brasil. Foram coletadas amostras de sangue e de pele integra de 143 cães, sendo aplicado um questionário. A deteç̧ão do DNA de L. infantum foi realizada através da PCR com os iniciadores RV1 e RV2. Os locais de coleta foram georreferenciados para realizar a distribuição e análise espacial das residências visitadas e dos cães infectados. DNA de $\boldsymbol{L}$. infantum foi detectado em 8,4\% (12/143) das amostras de pele dos cães e em 1,4\% (2/143) das amostras de sangue. No mapa de risco, foram observados três aglomerados em Itaboca e um em Menino Jesus de Petimandeua. Pôde-se constatar que a maioria dos moradores das comunidades quilombolas reside em áreas próximas de mata e não utilizam proteção contra insetos vetores. A presença de reservatórios caninos de L. infantum associada com características ambientais (floresta preservada e áreas de desmatamento) e os hábitos dos proprietários dos cães (que vivem perto de áreas de floresta e não usam qualquer tipo de proteção contra insetos) podem favorecer a transmissão de L. infantum nas áreas estudadas.

Palavras-chave: Leishmania infantum, comunidades quilombolas, cão, PCR, Amazônia Oriental.

\section{INTRODUCTION}

Visceral leishmaniasis is a zoonotic parasitic disease, with an incidence of 200,000400,000 human cases per year. More than $90 \%$ of visceral leishmaniasis cases occur in India, Bangladesh, Sudan, South Sudan, Ethiopia, and Brazil (CDC, 2016). According to the World Health Organization (2016), visceral leishmaniasis is a neglected tropical disease, particularly because it afflicts economically disadvantaged individuals from developing countries.
In Brazil, visceral leishmaniasis is caused by the protozoan $\boldsymbol{L}$. infantum (L. chagasi), which is transmitted principally by the phlebotomine species Lutzomyia longipalpis. Dogs are important domestic reservoirs of $\boldsymbol{L}$. infantum, and might serve as sentinels or indicators of the circulation of this etiologic agent in risk areas (MORAIS et al., 2013).

In the state of Pará, visceral leishmaniasis has spread to urban areas. Incidence of human cases has risen, which may be associated with human occupation of "ecolimits", the advance of deforestation, rural advancement adjacent to forested 
areas, rampant growth of human populations, and presence of animal reservoirs in urban and rural areas. In addition, other factors, including, the presence of natural conditions for the propagation of phlebotomine flies, adaptation of these insects to peri-household and household environments, delays in diagnosis and treatment, and a lack of control measures due to the preliminary nature of regional epidemiological data, could also be contributing to the current increase of visceral leishmaniasis cases in this region (FILHO \& SILVEIRA, 2007).

In the municipality of Inhangapi, Pará, there are six maroon communities that are selfrecognized and awaiting land tenure regularization (INCRA, 2015). Communities of Menino Jesus de Petimandeua and Itaboca are located in a rural area of the municipality where individuals could be exposed to leishmaniasis vectors and agents. In addition, the Secretaria de Saúde do Estado do Pará (SESPA, 2013) reported 22 human cases of cutaneous leishmaniasis and six human cases of visceral leishmaniasis in the municipality of Inhangapi between 2009 and 2013; however, data on the occurrence of natural infection by Leishmania spp. in dogs in this region are lacking. Therefore, the aim of this study was to detect $\boldsymbol{L}$. infantum infection in dogs and to evaluate factors associated with canine visceral leishmaniasis in the maroon communities of Menino Jesus de Petimandeua and Itaboca in the municipality of Inhangapi, Pará.

\section{MATERIALS AND METHODS}

\section{Study area}

The study was conducted in the municipality of Inhangapi $\left(01^{\circ} 25^{\prime} 45^{\prime \prime} \mathrm{S}\right.$ and $\left.47^{\circ} 55^{\prime} 11^{\prime \prime} \mathrm{W}\right)$, in the state of Pará, Brazil. Its population consists of 10,037 inhabitants (IBGE, 2015) spread over an area of $471 \mathrm{~km}^{2}$. The predominant vegetation is tropical forest, although deforestation has been registered in this region. The climate is megathermic and humid, with an average annual temperature of $25^{\circ} \mathrm{C}$, an average annual rainfall of $2.350 \mathrm{~mm}$, and an average relative humidity of approximately $85 \%$ (IDESP, 2014).

Sixty-eight residences were visited in the maroon communities of Menino Jesus de Petimandeua $(n=30)$ and Itaboca $(n=38)$, which are localized in a rural area of this municipality, corresponding to 292 residents. Residences were selected based on information from health officials. Before samples collection, educational pamphlets were distributed and lectures were given to residents and community health workers to raise awareness about the importance of leishmaniasis.

\section{Dog sampling}

From February to September, 2011, 143 domestic dogs (86 males and 57 females) of different ages ( $<6$ months, 6 months- 2 years, and $>2$ years) were examined. Of the $143 \mathrm{dogs}, 57$ were in Menino Jesus de Petimandeua and 86 were in Itaboca. Animals were classified as symptomatic (showing clinical signs of leishmaniasis, such as weight loss, cachexia, dermatologic alterations, onychogryphosis, lymphadenopathy, or kerato conjunctivitis) or asymptomatic (no clinical signs).

Whole blood and intact skin samples were aseptically collected from all study animals. Blood samples were collected by puncture of the cephalic vein using a syringe with a needle, stored in tubes containing ethylene diamine tetraacetic acid (EDTA), and frozen at $-20^{\circ} \mathrm{C}$ until analysis. To collect skin fragments, animals were tranquilized with acepromazine $\left(0.1 \mathrm{mgkg}^{-1}\right)$ via intramuscular injection. Local anesthesia ( $2 \%$ lidocaine hydrochloride; $0.5 \mathrm{mg}$ $\mathrm{kg}^{-1}$ ) was applied without a vasoconstrictor. A 6-mm (diameter) skin sample was obtained from the withers region of the dogs by punch biopsy. The wound was sutured with non-absorbable synthetic thread and needle, and a gentamicin-fibrinolysin ointment was applied to the skin to aid healing and prevent secondary infections. Skin fragments were placed in minitubes containing sterile saline $(1 \mathrm{~mL})$ and stored at $-20^{\circ} \mathrm{C}$ until DNA extraction.

\section{Molecular detection of $\boldsymbol{L}$. infantum}

DNA was extracted from blood and skin samples using the Illustra ${ }^{\mathrm{TM}}$ Blood Genomic Prep Mini Spin Kit (GE Healthcare) and the Illustra ${ }^{\mathrm{TM}}$ Tissue \& Cells Genomic Prep Mini Spin Kit (GE Healthcare), respectively, according to the manufacturer's instructions.

L. infantum DNA was detected by polymerase chain reaction (PCR) as previously described by GOMES et al. (2007), with some modifications. Primers RV1 (5'-CTTTTCTGGTCCCGCGGGTAGG-3') and RV2 (5'-CCACCTGGCCTATTTTACACCA-3') were used to amplify a 145-bp sequence from the LT1 fragment of $\boldsymbol{L}$. donovani group kDNA mini circles (LE FICHOUX et al., 1999). The DNA amplification reaction contained $2 \mu \mathrm{L}$ of test DNA ( 40ng), $10 \mathrm{~m}$ MTris (pH 8.3,50mMKCl), $1.5 \mathrm{mM} \mathrm{MgCl}_{2}, 200 \mu \mathrm{M}$ each nucleotide, $50 \mathrm{pmol}$ of each primer, and 2.5 units of Taq DNA polymerase (Ludwig Biotec) in a final volume of $25 \mu \mathrm{L}$. Reactions were performed in a thermal cycler (Veriti 96 Well Thermal Cycler; Applied Biosystems ${ }^{\circledR} 91$ ) using the following reaction 
conditions: $95^{\circ} \mathrm{C}$ for 5 minutes, followed by 40 cycles of $95^{\circ} \mathrm{C}$ for 30 seconds, $61^{\circ} \mathrm{C}$ for 30 seconds, and $72^{\circ} \mathrm{C}$ for 1 minute. A final extension was performed at $72^{\circ} \mathrm{C}$ for 10 minutes.

All reactions were carried with a negative control (DNA extracted from the blood and lymph node of a dog not infected and PCR negative), a positive control (DNA extracted from the blood and lymph node of a dog naturally infected by $L$. infantum, positive by imprint and PCR), and a contamination control (double distilled water instead of DNA). To test the specificity of the primers, reactions containing DNA from other isolated zoonotic protozoa, including Trypanosoma cruzi (amastigotes isolated from the cardiac muscle of a dog with acute Chagas disease), Leishmania amazonensis (MHOM/ $\mathrm{BR} / 2009 / 26361 \mathrm{P}$ promastigotes isolated at Instituto Evandro Chagas), and Leishmania braziliensis (MHOM/BR/1999/17593P promastigotes isolated at Instituto Evandro Chagas), were included in the experiment as controls.

The PCR products were analyzed by horizontal electrophoresis in a 1.5\% agarose gel and then stained with ethidium bromide $\left(0.5 \mathrm{mgmL}^{-1}\right)$. The amplified products were visualized on a transilluminator connected to a Quantum-ST4 1000/26M photo documentation system. The lengths of the amplified products were estimated by comparison to a 100-bp ladder (Ludwig Biotec).

\section{Collection of residence and canine data}

During residence visits, the owners of dogs answered a questionnaire containing information about the proximity of the residence to forested areas, the history of visceral leishmaniasis in family members, utilization of protective measures against arthropod vectors, origin of their dogs, and their approximate age ( $<6$ months, 6 months- 2 years, or $>2$ years).

\section{Statistical analysis}

The Chi-square test $\left(\chi^{2}\right)$ and Fisher's exact test were used to evaluate the association between the PCR results and the sex and age of dogs. Differences with $\mathrm{P}$ values less than or equal to 0.05 were considered statistically significant. Statistical analysis was performed using Bio Estat 5.0.

\section{Spatial distribution and analysis}

All the collection sites were georeferenced using GPS MAP equipment (60CSX; Garmin) to create risk maps using kernel density estimation (KDE) for animals infected by $\boldsymbol{L}$. infantum. A geographical information system (GIS) was used to convert the obtained coordinates into a base map, edit the obtained graphic elements, process spatial images, establish topological relationships between graphic elements and their respective attributes, perform spatial analyzes, and visualize the results by means of thematic maps. KDE is a statistical non-parametric interpolation technique that creates a continuous surface (cluster) of calculated densities in all locations; thus, allowing visual identification of hotspots without changing their local characteristics (BAILEY \& GATRELL, 1995).

To evaluate the environmental characteristics of the study areas (deforestation, forest, "occupations mosaic," pasture, reforestation, regeneration with pasture, and secondary vegetation), images from Land sat satellite $(223 / 61)$ and the classified images were uploaded to the PRODES $<$ http://www.obt.inpe.br/prodes/index.php $>$ and TERRACLASS Project <http://www.inpe.br/cra/ projetos_pesquisas/terraclass2012.php $>$ to make a land use map of the municipality of Inhangapi/PA. Shapes (limits, roads, hydrography, etc.) were also obtained from IBGE < http://www.ibge.gov.br/> and CPRM $<$ http://geobank.cprm.gov.br/>.

\section{RESULTS}

In the clinical examination, 5.6\% (8/143) of the animals presented suggestive clinical signs of canine visceral leishmaniasis, such as cachexia, skin lesions on the tips of the ears, alopecia, hyperkeratosis, lymphadenopathy, weight loss (most common clinical sign), and onychogryphosis.

L. infantum DNA was detected in $8.4 \%$ $(12 / 143)$ of the intact skin samples and $1.4 \%(2 / 143)$ of the blood samples. Eleven positive dogs were from Itaboca, and one positive animal was from Menino Jesus de Petimandeua (Figure 1A). Only one of the symptomatic animals was positive by PCR. None of the reactions amplified DNA from the other trypanosomatids with primers RV1 and RV2.

Most of dogs in the study group were $>2$ years old $(51.05 \%)$, followed by 6 months- 2 years old $(42.65 \%)$ and $<6$ months $(6.30 \%)$. Among the PCR positive animals, 50\% (6/12) were 6 months-2 years old, and $50 \%(6 / 12)$ were $>2$ years. In addition, among the PCR-positive dogs, 75\% (9/12) were male, and $25 \%(3 / 12)$ were female. Analyzing the group of positive animals according to sex and age revealed that most of the dogs were males $>2$ years $(55.56 \%)$ or males 6 months- 2 years $(44.44 \%)$. There were no significant differences between the three age ranges ( $<6$ months, $\mathrm{P}=0.42 ; 6$ months -2 years, $\mathrm{P}=0.48 ;>2$ 


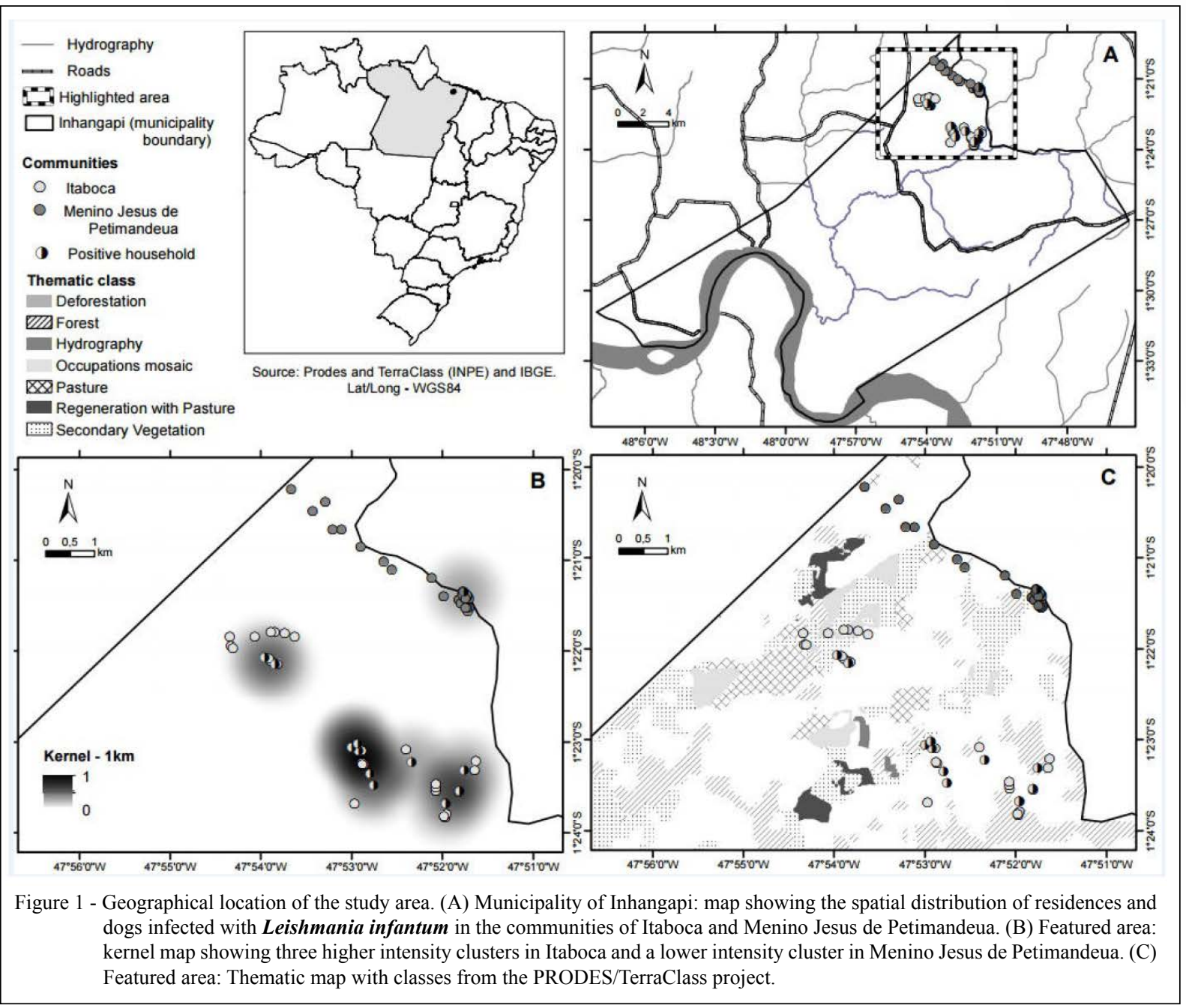

years, $\mathrm{P}=0.48$ ) and the PCR results. There were also no significant differences between the sex of the dogs $(\mathrm{P}=0.21)$ and the $\mathrm{PCR}$ results.

Origins of $95.1 \%(136 / 143)$ of the animals examined were known: $68.40 \%(93 / 136)$ were born in the municipality under study, and $31.61 \%$ (43/136) were born in another municipality of Pará. Nine positive dogs were born in Inhangapi, and three positive dogs were born in other municipality of Pará.

Regarding the location of residences, $83.83 \%$ (57/68) of positive animals were located within 100 meters of a forested area, and the remaining $16.17 \%(11 / 68)$ were located more than 100 meters from a forested area. Most of the positive animals were housed near forested areas, and $\boldsymbol{L}$. infantum infection could be associated with their proximity to forested and rural areas.

With respect to protection against arthropod vectors, $67.65 \%(46 / 68)$ of dog owners used no protection, $27.94 \%$ (19/68) used mosquito nets, $1.47 \%$ (1/68) used an insecticide, $1.47 \%(1 / 68)$ used mosquito nets and insecticide, and 1.47\% (1/68) used mosquito nets and a fan. During the study, there were no reports of human visceral leishmaniasis cases in the study communities.

The KDE of the study area, using a $1-\mathrm{km}$ radius, revealed three clusters in Itaboca and one in Menino Jesus de Petimandeua, and the cluster with the highest density was located in Itaboca (Figure 1B). Notably, $100 \%$ (38/38) of the studied households in Itaboca were located in the clusters, and $73.3 \%$ $(22 / 30)$ of the studied households in Menino Jesus de Petimandeua (Figure 1B) were located in the cluster.

According to PRODES project data, the extent of deforestation in the municipality of Inhangapi in 2013 was of $68.74 \%$. Figure 1C shows the land use classification from the PRODES and Terra Class 
Project data overlapped with clusters obtained from KDE in Itaboca and Menino Jesus de Petimandeua. Three of the clusters were in preserved areas, containing Amazon rainforest and secondary vegetation, while the remaining cluster, one cluster in Itaboca, was located in an area containing pasture and occupations mosaic. Areas are represented by an association of various land use arrangements, and due to the spatial resolution of the satellite images, it is not possible to discriminate the classes (TERRACLASS, 2012).

\section{DISCUSSION}

Visceral leishmaniasis is a serious public health problem in the Northern region of Brazil. During the period from 2009 to 2013, 3,311 human cases were confirmed in this region, and $41 \%$ of these cases were registered in the state of Pará (BRASIL, 2014).

The present study reported the first detection of $\boldsymbol{L}$. infantum DNA in domestic dogs in the municipality of Inhangapi. The detection rate for L. infantum DNA in intact skin samples was higher than that in blood samples. These data agree with the findings of QUARESMA et al. (2009), which detected by PCR higher positivity for Leishmania in dogs skin samples from the ear region $(80.2 \%)$ than in blood samples (75.3\%), as detected by PCR. QUEIROZ et al. (2010) collected skin samples from 34 naturally infected dogs that were serologically positive for Leishmania sp., and $100 \%$ of healthy skin samples and $95.6 \%$ of skin samples with lesions were positive by PCR. The age ranges and the sex of dogs in the maroon communities did not influence the PCR results, in agreement with the data reported by AMÓRA et al. (2006) and LAURENTI et al. (2013).

In Brazil, different clinical classifications have been used in studies of canine visceral leishmaniasis (MANCIANTI et al., 1988; GOMES et al., 2007; LAURENTI et al., 2013), and there is no consensus regarding the most appropriate clinical classification. Factors such as the clinical course of the disease, pathogenicity of the parasite, and the immune and nutritional status of the dogs are directly related to the presence or absence of clinical signs (REY, 2008). The majority of positive dogs in the municipality of Inhangapi were asymptomatic, and only one positive animal presented clinical signs suggestive of canine visceral leishmaniasis. According to LAURENTI et al. (2013), asymptomatic dogs are highly competent for the transmission of L. infantum to the phlebotomine vector, and these animals have an important role in the epidemiology of visceral leishmaniasis, by maintaining the transmission cycle of this agent in endemic areas. In addition, these authors observed that clinical severity was inversely related to the competence of dogs to promote infection of the vector.

Continuous deforestation is a serious environmental problem in Brazilian Amazon. The state of Pará has one of the highest rates of deforestation (PRODES website), and the municipality of Inhangapi has been registered as having high deforestation levels, mainly due to the replacement of forest for pasture. In both maroon communities was observed preserved forest area and deforested areas. In addition, Lu. longipalpis, the main vector of $\boldsymbol{L}$. infantum in Brazil, can establish breeding sites in forested areas, and has also been shown to adapt to degraded environments with anthropic activity (RANGEL \& VILELA, 2008; PINHEIRO et al., 2016). In this case, the transmission of $\boldsymbol{L}$. infantum to dogs in both maroon communities may be occurring at the interface between the peridomestic and wild environments.

The presence of sand fly vectors and numerous risk factors for infection, including the presence of $\boldsymbol{L}$. infantum reservoir dogs (LAURENTI et al., 2013), proximity of households to forested areas (ALMEIDA et al., 2009), and the habit of not using any protection against insect vectors (QUINTANILHA et al., 2016), may favor the spread of $\boldsymbol{L}$. infantum among humans in the studied areas.

\section{CONCLUSION}

The presence of canine reservoirs of $\boldsymbol{L}$. infantum in addition to the characteristics of the environment (preserved forests and deforested areas) and habits of dog owners (living near forested areas and not using any protection against insects) may favor the transmission of $\boldsymbol{L}$. infantum in the studied areas.

\section{ACKNOWLEDGMENTS}

The authors are especially thankful to the residents of the maroon communities and health officials for their important collaboration. The authors also thank Instituto Evandro Chagas (IEC) for the Leishmania amazonensis and Leishmania braziliensis isolates, and Fundação Amazônia Paraense (FAPESPA), PróReitoria de Pesquisa e Pós-graduação of Universidade Federal do Pará and Fundação de Amparo e Desenvolvimento da Pesquisa (FADESP) for financial support.

\section{BIOETHICS AND BIOSSECURITY COMMITTEE APPROVAL}

This study was approved by the Committee on Ethics in Animal Research (Comitê de Ética em Pesquisa com Animais de Experimentação - CEPAE) of the Universidade Federal do Pará (protocol number BIO067-12). 


\section{REFERENCES}

ALMEIDA, A.B.P.F. et al. Seroepidemiological survey of canine leishmaniasis in endemic areas of Cuiabá, State of Mato Grosso. Revista da Sociedade Brasileira de Medicina Tropical, v.42, n.2, p.156-159, 2009. Available from: <http://dx.doi.org/10.1590/ S0037-86822009000200012>. Accessed: 17 Aug. 2015. doi: $10.1590 /$ S0037-86822009000200012.

AMÓRA, S.S.A. et al. Factors related to positive testing of dogs for visceral leishmaniasis in endemic area in the state of Rio Grande do Norte, Brazil. Ciência Rural, v.36, n.6, p.1854-1859, 2006. Available from: <http://dx.doi. org/10.1590/S0103-84782006000600029>. Accessed: 12 Nov. 2015

BAILEY, T.C.; GATRELL, A.C. Interactive spatial data analysis. Harlow: Prentice Hall, 1995. 413p.

BRASIL. Situação Epidemiológica - Dados. Ministério da Saúde. Secretaria de Vigilância em Saúde. Departamento de Vigilância Epidemiológica. Brasília: Ministério da Saúde, 20014. Available from: $\quad<$ http://portalsaude.saude.gov.br/index.php/o-ministerio/ principal/leia-mais-o-ministerio/726-secretaria-svs/vigilancia-dea-a-z/leishmaniose-visceral-lv/11334-situacao-epidemiologicadados>. Accessed: 12 Jan. 2016

CDC (CENTERS FOR DISEASE CONTROL AND PREVENTION). Parasites - Leishmaniasis: Epidemiology \& Risk Factors. Available: <http://www.cdc.gov/parasites/ leishmaniasis/epi.html>. Accessed 04 Jan. 2016.

FILHO, M.S.R.; SILVEIRA, F.T. Epidemiologic, clinical and immunologic on the human Leishmania (Leishmania) infantum chagasi infection in endemic area of visceral leishmaniasis in Pará. Revista Paraense de Medicina, v.21, n.3, p.7-18, 2007. Available: <http://scielo.iec.pa.gov.br/pdf/rpm/v21n3/v21n3a02. pdf $>$. Accessed: 05 Jan. 2016.

GOMES, A.H.S. et al. PCR identification of Leishmania in diagnosis and control of canine leishmaniasis. Veterinary Parasitology. v.144, n.3-4, p.234-241, 2007. Available: <http:// www.sciencedirect.com/science/article/pii/S0304401706006030>. Accessed 05 Jan. 2016. doi: 10.1016/j.vetpar.2006.10.008.

IBGE (INSTITUTO BRASILEIRO DE GEOGRAFIA E ESTATÍSTICA). 2015. Available from: <http://www.ibge.gov. br/cidadesat/painel/painel.php?codmun=150340\#>. Online. Accessed: 03 Nov. 2015.

IDESP (INSTITUTO DE DESENVOLVIMENTO ECONÔMICO, SOCIAL E AMBIENTAL DO PARÁ). Estatística municipal - Inhangapi. 2014. Available from: <http://www.idesp.pa.gov. br/\#>. Online. Accessed: 03 Nov. 2015.

INCRA (INSTITUTO NACIONAL DE COLONIZAÇÃO E REFORMA AGRÁRIA) Quilombolas. Online. 2015. Available from: <http://www.incra.gov.br>. Accessed: 10 nov. 2015.

LAURENTI, M.D. et al. Asymptomatic dogs are highly competent to transmit Leishmania (Leishmania) infantum chagasi to the natural vector. Veterinary Parasitology, v.196, n.3-4, p.296-300, 2013. Available from: <http://www.sciencedirect.com/science/ article/pii/S0304401713001623>. Accessed: 22 Jan. 2016. doi: 10.1016/j.vetpar.2013.03.017
LE FICHOUX, Y. et al. Occurrence of Leishmania infantum parasitemia in asymptomatic blood donors living in an area of endemicity in Southern France. Journal of Clinical Microbiology, v.37, n.6, p.1953-1957, 1999. Available from: <http://jcm.asm.org/ content/37/6/1953.full.pdf+html>. Accessed: 22 Jan. 2016.

MANCIANTI, F. et al. Studies on canine leishmaniasis control. 1. evolution of infection of different clinical forms of canine leishmaniasis following antimonial treatment. Transactions of the Royal Society of Tropical Medicine and Hygiene, v.82, n.4, p.566-567, 1998. Available from: <http://www.sciencedirect.com/ science/article/pii/003592038890510X > . Accessed: 25 Jan. 2016. doi:10.1016/0035-9203(88)90510-X.

MORAIS, R.C. et al. Detection of Leishmania infantum in animals and their ectoparasites by conventional PCR and real time PCR. Experimental and Applied Acarology, v.59, p.473- 48, 2013. Available from: <http://link.springer.com/article/10.1007 \%2Fs10493-012-9611-4>. Accessed: 02 Jan. 2016. doi: 10.1007/ s10493-012-9611-4.

PINHEIRO, M.P.G. et al. Sand flies (Diptera, Psychodidae, Phlebotominae), vectors of Leishmania protozoa, at an Atlantic Forest Conservation Unit in the municipality of Nísia Floresta, Rio Grande do Norte state, Brazil. Parasites \& Vectors, v.9, n.83, p.18, 2016. Available from: <http://link.springer.com/article/10.1186/ s13071-016-1352-5?view=classic $>$. Accessed: 06 Feb. 2016. doi: 10.1186/s13071-016-1352-5.

QUARESMA, P.F. et al. Molecular diagnosis of canine visceral leishmaniasis: Identification of Leishamania species by PCRRFLP and quantification of parasite DNA by real-time PCR. Acta Tropica, v.111, n.3, p.289-294, 2009. Available from: <http://www. sciencedirect.com/science/article/pii/S0001706X09001193>. Accessed: 18 mar. 2015. doi:10.1016/j.actatropica.2009.05.008.

QUEIROZ, N.M.G.P. et al. Canine Visceral Leishmaniasis diagnosis by immunohistochemistry and PCR in skin tissues in association with RIFI and ELISA-test. Revista Brasileira de Parasitologia Veterinária, v.19, n.1, p.32-38, 2010. Available from: <http://dx.doi. org/10.4322/rbpv.01901006>. Accessed: 18 mar. 2015.

QUINTANILHA, M. F. et al. Factors associated with human visceral leishmaniasis: confirmed cases and co-inhabitants in Minas Gerais State, Brazil. Journal of Medical and Biological Science Research, v.2, n.1, p.5-13, 2016. Available from: <http://pearlresearchjournals. org/journals/jmbsr/index.html>. Accessed: 25 Feb. 2016.

RANGEL, E.F.; VILELA, M.L. Lutzomyia longipalpis (Diptera, Psychodidae, Phlebotominae) and urbanization of visceral leishmaniasis in Brazil. Cadernos de Saúde Pública, v.24, p.2948-2952, 2008. Available from: <http://dx.doi.org/10.1590/ S0102-311X2008001200025>. Accessed: 15 Aug. 2015.

REY, L. Leishmaníase visceral. In: REY, L. Bases de Parasitologia médica. Rio de Janeiro: Guanabara Koogan, 2008. Cap.6, p.63-70.

SESPA (SECRETARIA DE SAÚDE PÚBLICA DO ESTADO DO PARÁ). Leishmaníase visceral e tegumentar americana no município de Inhangapí. Boletim Epidemiológico, Departamento de Controle de Endemias, Castanhal, Pará. 2013.

WHO (WORLD HEALTH ORGANIZATION). Leishmaniasis. 2016. Available from: <http://www.who.int/mediacentre/ factsheets/fs375/en/>. Online. Accessed: 05 Jan. 2016. 